\title{
THE SUCCESS OF E-COMMERCE STARTUPS: AN EMPIRICAL STUDY IN VIETNAM
}

\author{
O SUCESSO DE STARTUPS DE COMÉRCIO ELETRÔNICO: UM ESTUDO EMPÍRICO NO VIETNÃ \\ EL ÉXITO DE LAS STARTUPS DE COMERCIO ELECTRÓNICO: UN ESTUDIO EMPÍRICO EN VIETNAM
}

Quoc Trung Pham ${ }^{1}$

Dinh Khang Pham ${ }^{2}$

\section{Cite as - American Psychological Association (APA)}

Pham, Q. T., \& Pham, D. K. (2021, Sept./Dec.). The success of e-commerce startups: an empirical study in Vietnam. International Journal of Innovation - IJI, São Paulo, 9(3), 622-645.

https://doi.org/10.5585/iji.v9i3.20233.

\begin{abstract}
Objective of the study: Although many e-commerce startups have been established in recent years, there is a high rate of business failure in start-up community. In addition, e-commerce in Vietnam is still at a beginning stage with many potentials and risks. The research aims to find impact factors which lead to the success of e-commerce startups in Vietnam.

Methodology/approach: The qualitative method was applied to identify appropriate measurement scales. Then, the quantitative questionnaire survey was leveraged to test the research framework based on data from local e-commerce startups.

Originality/Relevance: This research focuses on evaluating the impact of founder factors, e-service factors, and external factors on the success of startups in Vietnam.

Main results: Research findings show that four factors have significant contribution to e-commerce startups' success including risk-taking propensity, achievement orientation, reliability of e-service quality, and e-networking. Among the four, risk-taking propensity is the most contributed factor in ecommerce startups' success.

Theoretical/methodological contributions: The study helps to test the measurement scales and contributes an empirical study regarding to the success of startups in a developing country like Vietnam. Social/management contributions: Managerial implications for e-commerce incubators, entrepreneurs, and government are also recommended to improve the success rate of e-commerce startups in Vietnam.
\end{abstract}

Keywords: E-commerce. Startups. Entrepreneur. Success. Founder. E-service.

\section{Resumo}

Objetivo do estudo: Embora muitas startups de comércio eletrônico tenham sido estabelecidas nos últimos anos, há uma alta taxa de falência de negócios na comunidade de start-ups. Além disso, o comércio eletrônico no Vietnã ainda está em um estágio inicial com muitos potenciais e riscos. A pesquisa visa encontrar fatores de impacto que levam ao sucesso de startups de e-commerce no Vietnã.

\footnotetext{
${ }^{1}$ Doctor, Head of simulation lab., an associate professor at the Department of Management Information System, School of Industrial Management. Ho Chi Minh University of Technology (VNU-HCM) - Vietnam. pqtrung@ homut.edu.vn

${ }^{2}$ Master, Manager at Intel Products Vietnam. MBA, School of Industrial Management. Ho Chi Minh University of Technology (VNU-HCM) - Vietnam. pham.dinh.khang.hcm@gmail.com
} 
Metodologia / abordagem: O método qualitativo foi aplicado para identificar escalas de medição adequadas. Em seguida, a pesquisa por questionário quantitativo foi aproveitada para testar a estrutura de pesquisa com base em dados de startups de comércio eletrônico locais.

Originalidade / Relevância: Esta pesquisa se concentra na avaliação do impacto dos fatores fundadores, fatores de serviço eletrônico e fatores externos no sucesso de startups no Vietnã.

Principais resultados: Os resultados da pesquisa mostram que quatro fatores contribuem significativamente para o sucesso das startups de e-commerce, incluindo propensão a correr riscos, orientação para realização, confiabilidade da qualidade do serviço eletrônico e rede eletrônica. Entre os quatro, a propensão a correr riscos é o fator que mais contribui para o sucesso das startups de ecommerce.

Contribuições teórico-metodológicas: $\mathrm{O}$ estudo ajuda a testar as escalas de medição e contribui com um estudo empírico sobre o sucesso de startups em um país em desenvolvimento como o Vietnã.

Contribuições sociais / gerenciais: Implicações gerenciais para incubadoras de comércio eletrônico, empreendedores e governo também são recomendadas para melhorar a taxa de sucesso de startups de comércio eletrônico no Vietnã.

Palavras-chave: E-commerce. Startups. Empreendedor. Sucesso. Fundador. E-service.

\section{Resumen}

Objetivo del estudio: Aunque se han establecido muchas empresas emergentes de comercio electrónico en los últimos años, existe una alta tasa de fracaso empresarial en la comunidad de empresas emergentes. Además, el comercio electrónico en Vietnam se encuentra todavía en una etapa inicial con muchos potenciales y riesgos. La investigación tiene como objetivo encontrar factores de impacto que conduzcan al éxito de las nuevas empresas de comercio electrónico en Vietnam.

Metodología / enfoque: Se aplicó el método cualitativo para identificar las escalas de medición adecuadas. Luego, se aprovechó la encuesta del cuestionario cuantitativo para probar el marco de investigación basado en datos de empresas emergentes de comercio electrónico locales.

Originalidad / Relevancia: Esta investigación se centra en evaluar el impacto de los factores fundadores, los factores del servicio electrónico y los factores externos en el éxito de las empresas emergentes en Vietnam.

Principales resultados: los resultados de la investigación muestran que cuatro factores tienen una contribución significativa al éxito de las empresas emergentes de comercio electrónico, incluida la propensión a asumir riesgos, la orientación al logro, la confiabilidad de la calidad del servicio electrónico y las redes electrónicas. Entre los cuatro, la propensión a asumir riesgos es el factor que más contribuye al éxito de las empresas emergentes de comercio electrónico.

Contribuciones teóricas / metodológicas: El estudio ayuda a probar las escalas de medición y aporta un estudio empírico sobre el éxito de las startups en un país en desarrollo como Vietnam.

Contribuciones sociales / gerenciales: También se recomiendan las implicaciones de gestión para las incubadoras de comercio electrónico, los empresarios y el gobierno para mejorar la tasa de éxito de las nuevas empresas de comercio electrónico en Vietnam.

Palabras clave: E-commerce. Startups. Emprendedor. Éxito. Fundador. E-service.

\section{Introduction}

E-commerce is growing as a remarkable jump recently. It is considered to be one of the best strategies for developing a company or a country. By using e-commerce technology, it can support economic growth and development, ensure the sustainable developmental goals of countries; particularly in developing countries like Vietnam. 
Recent years in Vietnam, there is an observation of more and more businesses have begun to leverage e-commerce to conduct the businesses due to the advantages of e-commerce model. Especially high-tech devices such as smartphones and tablets are becoming more popular and affordable in society. Companies are using e-commerce as a medium to easily reach and communicate with the customers. Moreover, e-commerce is also considered as one of innovative technique, especially consumer goods and service providers, to better assist customers and potentially discover more about customers' needs.

Given the rapid trend of mobility in this decade, there are some observations of an increase in using the Internet to support personal activities such as entertainment, banking transaction, shopping, transportation, and air ticket booking. People tend to spend most of the time a day on doing things on the Internet at everywhere. Thus, there is a great opportunity to entrepreneurs to provide such kinds of service (or called e-commerce) and catch up with the new trend of customer purchasing behaviors. As a result, this is an interesting business sector, which potentially attracted entrepreneurs to establish an e-commerce venture. However, not all e-commerce companies or entrepreneurs can be successful after few years of running the business with given fact that business environment becomes more and more competitive. Regardless how violent the e-commerce market is, there are few entrepreneurs have found the precise ways to not only survive but also grow their business successfully.

According to Global Entrepreneurship Monitoring Vietnam 2015/16 report, the percentage of adults in Vietnam have fear of business failure was at a high level of $45.6 \%$ in 2015 , compared with $35.1 \%$ in factor-driven countries. In addition, the percentage of business discontinuance in 2015 was $3.7 \%$, meanwhile, $2.3 \%$ of business has to stop accompanies.

Based on this report, there was a detail of comparison between the rate of business discontinuance and total early-stage entrepreneurial activity (TEA). Based on this measure, the rate of business discontinuance was at $27 \%$, compared with the rate of TEA. This means that for every 100 people involved in TEA, there are 27 other people who give up the business. Likewise, for every 100 newly established businesses, 17 other business activities must stop. It was noted that these rates tend to increase compared to 2014. Those facts show the necessity of having a study related to critical success factors of entrepreneurs.

E-commerce has been demonstrating its numerous benefits as well as advantages which are applicable in modern life nowadays. It can help people create convenience and time-saving in many services where there is an internet accessibility. Although e-commerce services cost a big investment and risks, there are many of entrepreneurs still, want to jump into this emerging 
sector as an opportunity to catch up with the market trend as well as new customer behaviors. Therefore, the problem here is which factors suggested to have a positive effect on e-commerce entrepreneur's decision. If e-commerce entrepreneurs are aware of these factors as valid reference, it would be a great potential for their successful journey into the future. The success of e-commerce startups can be measured by the growth rate, sales volume, business stability, customer acceptance, or the overall satisfaction of entrepreneurs.

Hence, the intent of this study is to identify factors that impact the success of ecommerce startups or entrepreneurs in Vietnam. The research question will be what factors are critical to the success of e-commerce entrepreneurs? The followings are the main objectives of the research: (1) figure out what are possible factors made a start-up or entrepreneur in specific to be successful in e-commerce in Vietnam, and (2) give advice to startups as well as recommendations as managerial implications.

The structure of this paper is organized as follows: Section 2 presents main concepts and literature review, then, Section 3 summarizes hypotheses and research model. In section 4, the research process and research methods will be introduced, then, Section 5 provides main analysis results. Section 6 presents some discussions and implications, and finally, Section 7 will be conclusion and future research directions.

\section{Concepts \& literature review}

\subsection{E-commerce and e-business}

E-commerce is the purchasing and offering exercises of goods and services, or the transmitting of assets or information, over an electronic system, essentially the Internet (Turban et al., 2018). It is the utilization of electronic correspondences and computerized data, preparing innovation in business exchanges. Moreover, e-business refers to an across the board scope of online business exercises for goods and services. It likewise influences to any type of business exchange in which the gatherings communicate electronically instead of by physical trades or direct physical contact. There are three key players of e-commerce market, including government $(\mathrm{G})$, business $(\mathrm{B})$, consumer $(\mathrm{C})$. The various major types of e-commerce will be: business-to-business (B2B), business-to-consumer (B2C), business-to-government (B2G), consumer-to-customer (C2C), social commerce (s-commerce) \& mobile commerce (mcommerce). 


\subsection{E-commerce startups}

A start-up is an organization that is in the first phase of its operations. These organizations are frequently at first bankrolled by their entrepreneurial authors as they endeavor to exploit building up a product or service for which they believe it is a demand. In addition, a start-up is characterized as a venture or new business organization which in the initial phases of its improvement and intends to look for a scalable business model (Ries, 2011). The expression "start-up" has become well-known globally during the "dot-com bubble" when an extraordinary number of new website and businesses were established (Chakraborty \& Tyagi, 2020).

An entrepreneur is the person who makes a new business in the circumstance of risk and instability with the end goal of accomplishing profit and growth by distinguishing noteworthy opportunities and gathering the vital resources to capitalize on them. They are the individual who is beyond a business maker; they are change agents in the public arena. An entrepreneur has the qualities of looking for opportunities, stepping out a comfort zone, and having the perseverance to test their ideas in practice. Moreover, all the benefits of entrepreneurship originate from the work of the entrepreneur, who makes new endeavors, confronts various dangers and instabilities on their approach to achievement (Kuratko \& Hodgetts, 2004; Blank \& Dorf, 2012).

\subsection{Vietnamese e-commerce start-up}

Since 2016, Vietnam e-commerce has entered faster growth. According to 2015 Vietnam E-commerce Association (VECOM) report, there are existing big obstacles remain unchanged, including customers' low trust on online shopping, unpopular online payment, and unqualified delivery and fulfillment services. Vietnam E-Commerce Association judges that from 2016, Vietnamese e-commerce will turn to a rapid growth phase, which opens opportunities for different stakeholders, such as: delivery and fulfillment services.

In 2015, as a result taken from a survey of adults in Vietnam, $56.8 \%$ of respondents shown as having sufficient knowledge, skills, and experiences of starting up a business. Vietnam ranked the $19^{\text {th }} / 60$ on the entrepreneurial awareness. The proportion of people intending to start a business in Vietnam is $22.3 \%$, ranking the 23 rd out of 60 countries. Compared with other countries in the ASEAN region, the rate of people intending to start a business in Vietnam is higher than Thailand (ranking the 31st) and Malaysia (ranking the 57th), 
and developing trend of the entrepreneur community in Vietnam is increasing annually (GEM, 2017; GEM, 2020).

GEM (2017) has listed down some reasons of business discontinuance and the main reason is a financial problem, account for $29 \%$. The followings are that their business is unprofitable (22.2\%), job opportunity or entrepreneurs found another opportunity $(19.4 \%)$, the personal reason (11.1\%) and planned exit (9.7\%). In addition to the above-mentioned reasons, taxes or administrative procedures in Vietnam also contributes to business discontinuance.

According to a report of Australian Embassy (2019), Vietnam has the third-highest rate for startups in Southeast Asia. In 2016, Prime Minister Nguyen Xuan Phuc emphasized entrepreneurship as a key driver for economic growth and approved the "Supporting National Innovative Start-up Ecosystem to 2025" project to build a platform for the sector's growth. Based on this report, challenges facing Vietnam's innovation ecosystem include: Ability to access finance, Talent and entrepreneurship skills, Fragmented ecosystem, R\&D capabilities, and Intellectual Property (IP) issues.

\subsection{Critical factors for e-commerce success}

Critical success factors (CSFs) are things that need to be going well in order to enable an individual or an organization to ensure the success of a business undertaking. The basic of analyzing and identifying the critical factors for new ventures is a key to reducing the number of start-up failures (Groenewegen \& De Langen, 2012). Success can be measured by various criteria, such as sales growth, income, employment trends, and satisfaction. Besides, the success of a start-up business could include two distinct dimensions: economic success and entrepreneur's satisfaction. Fisher et al. (2014) suggested that the construct of entrepreneurial success should be a combination of personal and business performance indicators.

\subsection{Related research}

Chen et al. (2003) summarized those factors impact to e-commerce as followings: incremental e-commerce involvement, allocate resource wisely, outsource the development, change business practices, study the customer, revise and evaluate results.

Thornton \& Marche (2003) also presented in their research those factors impact to ecommerce as followings: industry experience of management, planning/strategy, capital, recordkeeping financial control, expansion growth, inventory/channel management, 
advertising/marketing strategies, market position, target market, customer service/experience, clear value proposition.

Quaddus \& Achjari (2005) proposed an electronic commerce success research model with four key factors: (1) internal driver consists of cost leadership, reputation, market, and business entry; (2) internal impediments consist of finance, risk, and expertise; (3) external driver consists of product pricing, time spent, convenience, and external relationship; and (4) external impediments consist of customer's expense, delivery time, transaction risks, and access.

Sung (2006) has created a summary table of consolidation of CSFs of e-commerce from extensive literature review 40 studies. The 16 CSFs are identified as follows: customer relationship, privacy of information, low-cost operation, ease of use, e-commerce strategy, technical e-commerce expertise, stability of systems, security of systems, plenty of information, variety of goods/services, speed of systems, payment process, services, delivery of goods/services, low price of goods/services, and evaluation of e-commerce operations.

Sebora et al. (2009), based on empirical studies of Thai e-commerce startups, proposed CSFs for e-commerce startups, include achievement orientation, locus of control, and an emphasis on e-service quality such as the reliability, responsiveness, ease of use, and selfservice features.

Nguyen (2010) mentioned in her research some recommendations for Vietnamese ecommerce enterprises to attract more customers toward using e-commerce that are ease of use, variety online payment methods, security of customer info, knowledgeable and skilled staffs, identified business plan to attract more foreign investors.

In the study of Choshin \& Ghaffari (2017), they investigated the impact of effective factors on the success of e-commerce in small- and medium-sized companies. Their research had mentioned to four hypotheses: the first one is customer satisfaction, the second one is cost, the third one is infrastructure, and the last one is individuals' awareness and knowledge.

Another research on digital startup success from Indonesia (Dessyana \& Riyanti, 2017) found that personalities factor of founders had a contribution in business development, especially entrepreneurial self-efficacy (ESE) and innovation. According to this result, ESE has significant positive effect on the digital startup success.

Recently, Santos \& Torkomian (2021) found that the main characteristics of digital entrepreneurs are related to gender, age, academic background, professional experience, and 
personal knowledge and skills in the chosen sector. So, personalities and characteristics of founders can predict and facilitate the success of the e-commerce startups.

\section{Hypotheses \& research model}

\subsection{Research hypothesis}

\section{$\underline{3.1 .1 \text { Founder factors }}$}

Personality traits are predictable characteristic of individual behavior which assists in explaining the differences of individual actions in similar situations (Llewellyn \& Wilson, 2003). Personality theories emphasize the importance of entrepreneurs' personal characteristics for the success of any start-up (Kerr, Kerr \& Xu, 2017; Santos \& Torkomian, 2021). Ecommerce entrepreneurs with an achievement orientation will be more successful than others (Jones \& Tynan, 2021). Therefore, hypothesis 1 could be stated as follows:

Hypothesis 1: Achievement orientation positively impacts on the success of e-commerce startups in Vietnam.

Risk taking is critical for an entrepreneurs' characteristic. Successful entrepreneurs are usually willing to take risks (Kuratko \& Hodgetts, 2004). Risk taking is defined as the perceived probability of receiving the rewards associated with success of a proposed situation and strongly related to the success of entrepreneur (Macko \& Tyszka, 2009; Jones \& Tynan, 2021). Therefore, hypothesis 2 is stated as follows:

Hypothesis 2: Risk-taking propensity positively impacts on the success of e-commerce startups in Vietnam.

Locus of control refers to the entrepreneurial perception that all situations are under their control and influence. This has been identified as the most dominant entrepreneur characteristic. Internal locus of control will lead to the self-confidence of entrepreneurs, as a result, it leads to the success of a start-up (Sebora et al., 2009; Dessyana \& Riyanti, 2017). Therefore, hypothesis 3 could be stated as follows: 
Hypothesis 3: Locus of control positively impacts on the success of e-commerce startup in Vietnam.

E-networking refers to the ability of entrepreneurs in communicating and doing business with new technologies on the Internet, such as social media, mobile and collaboration platforms. As a result of e-networking, entrepreneurs are changing their communication, collaboration methods, and the way they do business (Sung, 2006). Nowadays, digitization makes it easy for products and services to be distributed through various information-based supply channels. Through the Internet, e-commerce entrepreneurs can get the information faster with a low cost, which will lead to the success of their businesses (Chakraborty \& Tyagi, 2020). Therefore, hypothesis 4 could be stated as follows:

Hypothesis 4: E-networking positively impacts on the success of e-commerce startup in Vietnam.

\subsubsection{E-Service factors}

Service quality is the most important of all services (Zeithaml, 2002). Reliability is the capacity to direct the service precisely and reliably, including recurrence of refreshing the site, incite answer to a client request, and accuracy of web based buying and charging (Santos, 2003). Reliability is confirmed one of the most important factors for the success of any e-commerce website (Sebora et al., 2009). Therefore, hypothesis 5 could be stated as follows:

Hypothesis 5: Reliability of e-service quality positively impacts on the success of ecommerce startup in Vietnam.

Responsiveness is the capacity to manage complaints and quickness of services (Van Riel et al., 2003). The speed of delivery of service and user satisfaction are correlated. Customers anticipate that the Internet retailers will react to their inquiries punctually (Choshin \& Ghaffari, 2017). Prompt responses help customers resolve their problems and make decisions faster, which will lead to the success of the startup. Therefore, hypothesis 6 is stated as follows:

Hypothesis 6: Responsiveness of e-service quality positively impacts on the success of e-commerce startup in Vietnam. 
Usability is the most vital need to satisfy potential clients for e-commerce startups (Nguyen, 2010). Online clients may easily quit as opposed to endure numerous specialized troubles while doing web based shopping. In this way, simple access to significant data is an absolute necessity prerequisite of web based business. Convenience includes effortlessness, clear, easy to understand and concise content. Pham et al. (2018) showed that convenience is very important for the success of an e-commerce website in Vietnam. Clients need to find required items/administrations and direct exchange rapidly. Therefore, the hypothesis 7 is stated as follows:

Hypothesis 7: Ease of use of e-service quality positively impacts on the success of ecommerce startup in Vietnam.

The development of technology-based self-service formats will enable consumers to conduct the services for themselves quickly and conveniently (Bobbitt \& Dabholkar, 2001; Chakraborty \& Tyagi, 2020). By doing this, the cost of customer services (like support call center) will be reduced significantly because customers can take to find the answers to their questions within shortest time (like FQA section - frequently asked questions). Self-service could help to increase the satisfaction and decrease the cost for customers (Sebora et al., 2009). Therefore, hypothesis 8 could be stated as follows:

Hypothesis 8: Self-service of e-service quality positively impacts on the success of ecommerce startup in Vietnam.

\section{$\underline{\text { 3.1.3 External factor }}$}

The support from government is important to intendancy of an e-commerce business start and development in this dynamic environment. The support can come from the benefits of financial budgets, related policies, and a wide range of programs and procedures to facilitate and enhance entrepreneur activities (Reynolds et al., 2002). In Vietnam, there is a lack of appropriate policy for e-commerce development. Therefore, hypothesis 9 could be stated as follows:

Hypothesis 9: Government support positively impacts on the success of e-commerce startup in Vietnam. 


\subsection{Research model}

From the above discussion, the research model could be illustrated by the following figure.

\section{Figure 1}

The proposed research model

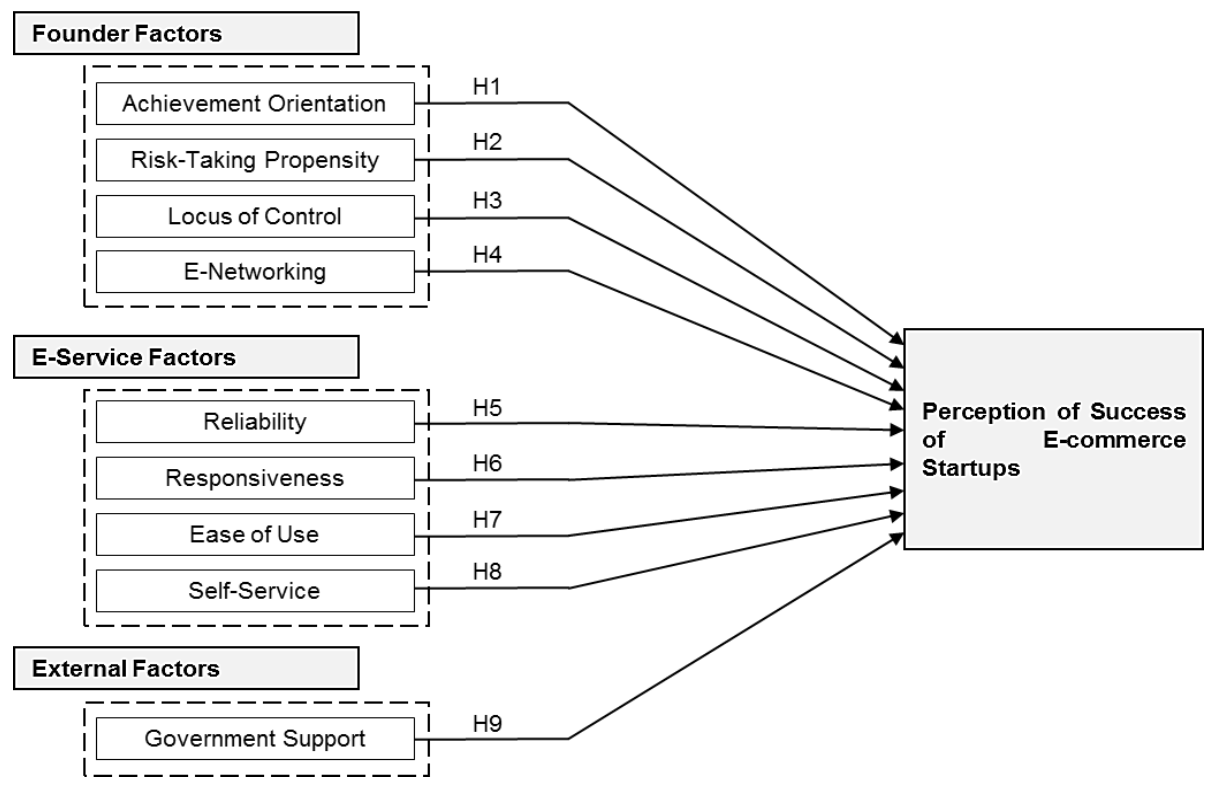

Adapted from: Sebora et al., 2009.

\section{Research process}

The research will have two stages to collect sufficient information - qualitative and quantitative approach. A qualitative approach will help to identify what are critical success factors of e-commerce startups by taking a literature review of relevant research topics, existing theories, and situation in Vietnam context. From the findings from the qualitative approach, the next step is a quantitative approach which using identified questionnaires formed from the previous stage to measure the theories and hypothesis. The process of this research will be described by below flow chart: 


\section{Figure 2}

The research process flow chart

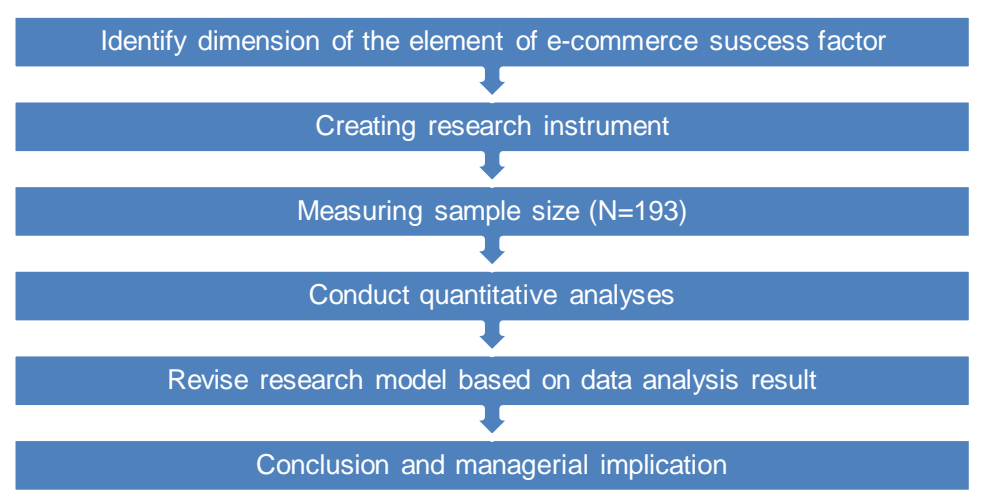

Adapted from: Hair et al., 2014.

The scales will be the Likert scales with five points where from 1 to 5 ("Strongly disagree" to "Strongly agree"). There are total 37 measurements which are adopted from previous researches. There are four factor groups that are founder's factors, e-service quality factors, external factors, and e-commerce start-up success.

A preliminary qualitative approach was conducted by interview sessions with five persons who have experience in e-commerce field. The interview was carried through both face-to-face interview and tele-interview ways. In summary, there were not much changes either adding new measurement item or removing existing measurement item. All of measurement scales were maintained as original version. However, the wording arrangement and meaning of some sentences in Vietnamese version were modified to adapt with local language. The final questionnaire survey then was created after assessing all contributions from qualitative approach.

The target population for this research involves of all e-commerce entrepreneurs, managers, and startups in Vietnam. All business fields are considered such as manufacturing, trading, services, others. The sample selection is based on the criterion that the firm had to be established for at least three months. The expected sample size of the study is 185 which is satisfied to run a multiple regression based on the recommendation of minimal sample size formula suggested by Tabachnick \& Fidell (2007).

There are several channels to support data collection. All of possible sources of target respondents are addressed by the researcher through multiple approaches. Then, the collected data will be tested by SPSS software. Several techniques for data analysis will be used, including Descriptive statistics, Cronbach's Alpha, Exploratory factor analysis, and multiple linear regression for the hypothesis test, etc. 


\section{Analysis results}

\subsection{Sample size and description statistics}

The research questionnaire survey was conducted in six weeks, resulted in 193 valid responses from targeted groups of e-commerce entrepreneurs and managers in Vietnam, mainly in Ho Chi Minh City and Ha Noi. The main approach of questionnaire survey was in an online form which could help significantly reduce time and easily expand to mass respondents. Each of the respondents were highly recommended to send the survey through their networks such as colleagues, friends, and online forum who were relevant. The questionnaire survey was spread out by multiple channels such as private emails, posts in Facebook, and other instant messenger forms. The questionnaire survey was also sent to SME Networking and Mentoring Program Vietnam. The researcher also sent emails to groups of people who their email addresses published on Vietnam E-commerce Association (VECOM). Table 1 below shows some general information of collected samples. In term of gender, male was dominant (93.3\%). This indicator made sense because e-commerce generally is a technology based business, man is used to be dominant in term of quantity during university time, which is typical in Vietnam. The majority of respondents' age was from 35 to 44 (50.3\%). It is easy to understand because at this range of age, people are become maturity in term of logical thinking and experience. Therefore, they are able to upskill competency to become a manager and establish ownedbusiness. The number of owner or manager in the company which was more than six people were at a high percentage of respondents $(45.1 \%)$, as well as number of staff from 11 to 50 people $(34.2 \%)$, and most of them worked in the services field (41.5\%) with years of operating were more than three (48.2\%), the majority of them held a diploma or bachelor degree $(76.7 \%)$. 


\section{Table 1}

\section{Description of data collection}

\begin{tabular}{|c|c|c|c|c|}
\hline & Description & Frequency & $\begin{array}{l}\text { Percent } \\
(\%)\end{array}$ & $\begin{array}{l}\text { Cumulative } \\
\text { Percent }(\%) \\
\end{array}$ \\
\hline \multirow[t]{2}{*}{ Gender } & Male & 180 & 93.3 & 93.3 \\
\hline & Female & 13 & 6.7 & 100 \\
\hline \multirow[t]{4}{*}{ Age } & $18-24$ & 15 & 7.8 & 7.8 \\
\hline & $25-34$ & 74 & 38.3 & 46.1 \\
\hline & $35-44$ & 97 & 50.3 & 96.4 \\
\hline & $45-54$ & 7 & 3.6 & 100 \\
\hline \multirow{4}{*}{$\begin{array}{l}\text { Number of } \\
\text { Owner/Manager }\end{array}$} & 01 & 28 & 14.5 & 14.5 \\
\hline & 02 & 41 & 21.2 & 35.8 \\
\hline & $03-05$ & 37 & 19.2 & 54.9 \\
\hline & More than 06 & 87 & 45.1 & 100 \\
\hline \multirow[t]{4}{*}{ Business Field } & Production/Manufacturing & 12 & 6.2 & 6.2 \\
\hline & Services & 80 & 41.5 & 47.7 \\
\hline & Trading & 61 & 31.6 & 79.3 \\
\hline & Others & 40 & 20.7 & 100 \\
\hline \multirow[t]{5}{*}{ Number of Staff } & Less than 05 & 46 & 23.8 & 23.8 \\
\hline & $06-10$ & 49 & 25.4 & 49.2 \\
\hline & $11-50$ & 66 & 34.2 & 83.4 \\
\hline & $51-100$ & 19 & 9.8 & 93.3 \\
\hline & More than 100 & 13 & 6.7 & 100 \\
\hline \multirow{5}{*}{$\begin{array}{l}\text { Years of } \\
\text { Operating }\end{array}$} & From 03 to 06 months & 8 & 4.1 & 4.1 \\
\hline & 06 months -01 year & 35 & 18.1 & 22.3 \\
\hline & $01-02$ years & 2 & 1.0 & 23.3 \\
\hline & $02-03$ years & 55 & 28.5 & 51.8 \\
\hline & More than 03 years & 93 & 48.2 & 100 \\
\hline \multirow{2}{*}{$\begin{array}{l}\text { Educational } \\
\text { Level }\end{array}$} & Diploma or Bachelor degree & 148 & 76.7 & 76.7 \\
\hline & Master degree or higher & 45 & 23.3 & 100 \\
\hline
\end{tabular}

Source: Analysis results

\subsection{Reliability test}

The purpose of reliability testing was to measure internal consistency among the variables in a scale. Meaning all individual items of the scale should all be measuring the same construct and be highly inter-correlated (Hair et al., 2014). The most widely used measure was Cronbach's alpha. According to Hair et al. (2014), the reliability score as measured by Cronbach's alpha should be greater than or equal 0.70 , but a 0.60 level could be acceptable. Besides, the corrected item-total correlation must be greater than or equal 0.3 .

As per the result, there were three items (REL17, SES27, and GOV33) were removed. The item REL17 which was under Reliability scales had Corrected Item-Total Correlation below $0.3(0.201)$, thus it should be eliminated. After that, reliability test was run again with only two items (REL18 \& REL19), the result was improved significantly, and Cronbach's alpha value went up to 0.716. Similarly, the item SES27 and GOV33 encountered an issue with low Corrected Item-Total Correlation of 0.284 and 0.279 respectively, so that they were removed out of the list. After that, the second reliability test for Self-Service and Government Support 
was run again. The testing results were improved with Cronbach's alpha value of Self-Service went up to 0.775 versus 0.662 , and Cronbach's alpha value of Government Support went up to 0.673 versus 0.639 from the first test. The rest of scales met defined criteria' for the next test.

\subsection{Factor analysis - exploratory test}

There were two main approaches to factor analysis - exploratory and confirmatory. At this step, the Joint Exploratory Factor Analysis (EFA) was run for nine independent variables to explore the interrelationships among a set of variables. The extraction method used was Principal Component Analysis and Rotation Method was Promax.

According to Pallant (2005), Kaiser-Meyer-Olkin Measure of Sampling Adequacy (KMO) value is 0.6 or above, and The Barlett's Test of Sphericity value should be significant (Sig. value should be less than 0.05). In this case, as per Table 18 below, the Kaiser-MeyerOlkin Measure of Sampling Adequacy (KMO) value is 0.716 and the Bartlett's Test is significant (Sig. is 0.000), therefore factor analysis was appropriate.

A new set of components that have an eigenvalue of 1 or more is considered (Pallant, 2005). According to Total Variance analysis, the first nine components recorded eigenvalues above 1, these nine components explained a total of 63.192 percent (\% Cumulative) of the variance. Therefore, the first nine components or factors were determined for the next step.

At the first time of running EFA test, there were only nine components were shown up in the right hand side because in the Extraction method, SPSS only extracted components had eigenvalues greater than 1 . As per the result, there were two abnormalities which violated minimal required factor loading value of 0.5, which are EOU25 and ACO03. Therefore, the two factors were eliminated in the second EFA test. The remaining loading factors were acceptable because they met two conditions: (1) factor loading values were greater than 0.5 and (2) absolute differences in cross-factor loadings were greater than 0.3 (Hair et al., 2014).

After eliminating two items ACO03 and EOU25, the second EFA test was conducted. By looking at Pattern Matrix, all independent variables were unidimensional. Total nine factors were retained, and 28 items loaded significantly. There were two significant outcomes of the Joint EFA test. The first one, factor loadings of all remained items were larger than 0.5 , thus the convergent validity was accessed. The second one, almost items were loaded on only one component. Although there were cross-loading cases, the absolute differentials were till greater than 0.3; thus, the items were retained. Discriminant validity of the scales was assessed. In summary, final results were qualified for further analyses. 


\subsection{Multiple regression analysis}

This section provided an assessment of the fitness of the overall model. The focus here was adjusted $\mathrm{R}$ square value rather than $\mathrm{R}$ Square because this study involved a small sample size (Pallant, 2005). Thus, the adjusted R Square provided a better estimate of the true population value. Adjusted R square measured overall model predictive accuracy. By looking at Table 2, adjusted R Square was adjusted R Square was 0.419, meaning 41.9 percent of the variance in entrepreneurial success could be explained by this model.

\section{Table 2}

Model summary - multiple regression analysis

\begin{tabular}{rl|c|c|c}
\hline \multicolumn{5}{c}{ Model Summary $^{\mathbf{b}}$} \\
\hline Model & $R$ & $R$ Square & Adjusted $R$ Square & Std. Error of the Estimate \\
\hline 1 & $.668^{\mathrm{a}}$ & 0.446 & $\mathbf{0 . 4 1 9}$ & 0.51318 \\
\hline \multicolumn{6}{l}{ a. Predictors: (Constant), M_GOV, M_LOC, M_REL, M_RES, M_EOU, M_SES, M_ACO, M_NWK, M_RIS } \\
b. Dependent Variable: $M$ SUC
\end{tabular}

Source: Analysis results.

It was necessary to assess the statistical significance of the result. In the ANOVA table (Table 3), the Sig. value (0.000) meant this model was statistical significance.

Table 3

ANOVA - multiple regression analysis

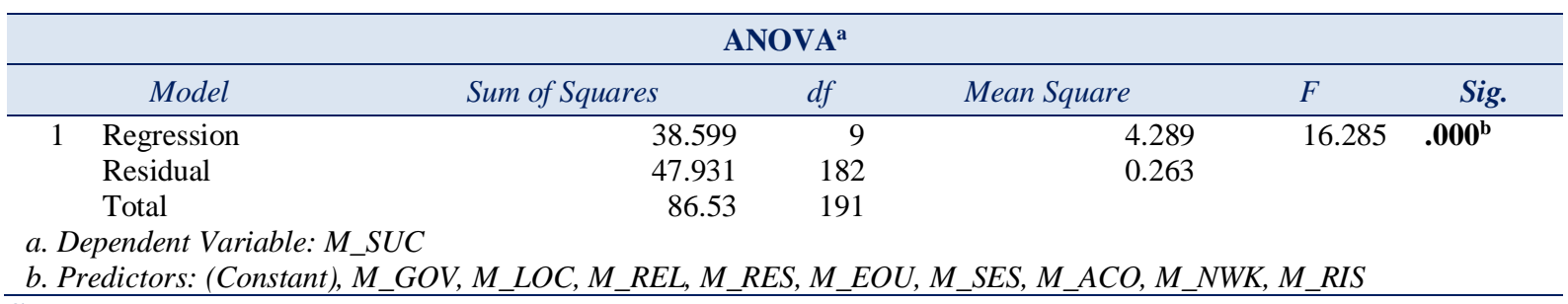

Source: Analysis results.

In Coefficient table (Table 4) below, under Standardized Coefficients column, the largest Beta value was 0.522 which belonged to Risk Taking Propensity factor. This meant that this variable made the strongest contribution to explain the dependent variable (Entrepreneur Success). Following by Achievement Orientation factor which had Beta value was 0.171, and the other two were Reliability and E-Networking which have Beta values were 0.131 and 0.124 respectively. 
In this study, there were four independent variables have Sig. values less than 0.05 , they were Achievement orientation, Risk taking propensity, E-networking, and Reliability; meaning that they made a statistical significance in predicting of Entrepreneur Success. The other five variables, which had Sig. values greater than 0.05 , were not making a significant contribution to the prediction of Entrepreneur Success.

\section{Table 4}

Coefficients - multiple regression analysis

\begin{tabular}{|c|c|c|c|c|c|c|c|}
\hline \multicolumn{8}{|c|}{ Coefficients $^{a}$} \\
\hline \multirow[t]{2}{*}{ Model } & \multicolumn{2}{|c|}{ Unstandardized Coefficients } & \multirow{2}{*}{$\frac{\text { Standardized Coefficients }}{\text { Beta }}$} & \multirow{2}{*}{$\mathrm{t}$} & \multirow{2}{*}{ Sig. } & \multicolumn{2}{|c|}{ Collinearity Statistics } \\
\hline & $\mathrm{B}$ & Std. Error & & & & Tolerance & VIF \\
\hline 1 (Constant) & 0.811 & 0.340 & & 2.390 & 0.018 & & \\
\hline Achievement Orientation & 0.152 & 0.057 & 0.171 & 2.678 & 0.008 & 0.750 & 1.334 \\
\hline Risk-taking Propensity & 0.458 & 0.062 & 0.522 & 7.428 & 0.000 & 0.617 & 1.621 \\
\hline Locus of Control & 0.005 & 0.049 & 0.006 & 0.093 & 0.926 & 0.794 & 1.260 \\
\hline E-networking & 0.112 & 0.057 & 0.124 & 1.970 & 0.050 & 0.769 & 1.300 \\
\hline Reliability & 0.082 & 0.037 & 0.131 & 2.251 & 0.026 & 0.903 & 1.107 \\
\hline Responsiveness & -0.020 & 0.040 & -0.030 & -0.508 & 0.612 & 0.890 & 1.123 \\
\hline Ease of Use & 0.090 & 0.058 & 0.094 & 1.538 & 0.126 & 0.821 & 1.218 \\
\hline Self-service & -0.065 & 0.048 & -0.085 & -1.366 & 0.174 & 0.782 & 1.278 \\
\hline Government Support & -0.040 & 0.052 & -0.047 & -0.770 & 0.442 & 0.830 & 1.204 \\
\hline
\end{tabular}

Source: Analysis results.

For testing the proposed hypotheses, the sig. value was used to check whether the impact was statistically significant or not (at $95 \%$ significance level). Table 5 summarized the hypothesis test results.

\section{Table 5}

Summary results of hypothesis test

\begin{tabular}{lcccc}
\hline \multicolumn{1}{c}{ Hypotheses } & Beta & $\begin{array}{c}\text { Std. } \\
\text { Erro } \\
\text { r }\end{array}$ & Sig. & Result \\
\hline H1: Founder's achievement orientation $=>$ & $\mathbf{0 . 1 7 1}$ & 0.057 & $\mathbf{0 . 0 0 8}$ & Supported \\
Success & $\mathbf{0 . 5 2 2}$ & 0.062 & $\mathbf{0 . 0 0 0}$ & Supported \\
H2: Founder's risk-taking propensity => Success & 0.006 & 0.049 & 0.926 & Rejected \\
H3: Founder's locus of control => Success & $\mathbf{0 . 1 2 4}$ & 0.057 & $\mathbf{0 . 0 5 0}$ & Supported \\
H4: Founder's e-networking => Success & $\mathbf{0 . 1 3 1}$ & 0.037 & $\mathbf{0 . 0 2 6}$ & Supported \\
H5: E-service reliability => Success & -0.030 & 0.040 & 0.612 & Rejected \\
H6: E-service responsiveness => Success & 0.094 & 0.058 & 0.126 & Rejected \\
H7: E-service ease of use => Success & -0.085 & 0.048 & 0.174 & Rejected \\
H8: E-service self-service => Success & -0.047 & 0.052 & 0.442 & Rejected \\
H9: Government support => Success & & & &
\end{tabular}

Source: Analysis results. 


\section{Discussion \& implications}

\subsection{Discussion}

The results of this study are a little bit different from (Sebora et al., 2009) happened in Thailand in term of supported factors. In this research, after research analysis, there are four of nine factors remained, risk-taking propensity, achievement orientation, e-service reliability, and e-networking. Meanwhile, the supported factors of (Sebora et al., 2009) are locus of control, eservice reliability, e-service ease of use, and founder's achievement orientation. The most significant contributing factor in this research is risk-taking propensity, meanwhile in research of (Sebora et al., 2009) is locus of control which aligns with other research results. Table 6 below provides a breakdown detail of the significant contribution of supported factors between the two studies. This differentiation can be understood because of (1) different study timeframe, the world is changing rapidly in term of technology development when industrial revolution 4.0 is happening; and (2) entrepreneurial ecosystem in Vietnam is not as same as Thailand such as physical infrastructure, governmental programs, and commercial infrastructure.

\section{Table 6}

Results comparison with the previous research

\begin{tabular}{l|c|l|r}
\hline Findings from this research & \multicolumn{1}{|c|}{ Beta } & Findings from (Sebora et al., 2009) & Beta \\
\hline Risk-taking propensity & 0.52 & Locus of control & 0.48 \\
\hline Achievement orientation & 0.17 & Reliability of e-service quality & 0.32 \\
\hline Reliability of e-service quality & 0.13 & Ease of use of e-service quality & 0.19 \\
\hline E-networking & 0.12 & Achievement orientation & 0.09 \\
\hline
\end{tabular}

Source: Analysis results.

For the rejected hypotheses (locus of control, responsiveness, ease of use, self-service and government support), most factors belong to e-Service quality and government support. This means that the current government policies and infrastructure for e-Services are poor and should be improved for encouraging the development of startup businesses.

Together with these questions of measurement scales, there are two extended questions which helps to have further understanding of feedbacks of respondents.

Question 1: What is the biggest obstacle of your business?

The answers from extended question one, that's including capital investment, government support (clear and transparent local regulations, tax support), human resources (qualified staffs), business management experience, looking for new customers, customers' 
behaviors, long-term race. These give us some hints which are beyond the scope of this study about existing risks or difficulties when conducting a business in Vietnam, which are similar to previous researches in Vietnam (Pham, 2017). To be successful, a startup has to face with both internal and external problems which are not limited to the result of this study.

Question 2: What kind of government support do you expect to receive most?

The answers from extended question two, that's including transparency of government policy, low interest rate, capital support, marketing support, creating a start-up community where they can work with each other's. As the result, it is a clear evidence that government support is a required factor which start-up need to push up their performance. These are very helpful glues that the government can look at to develop more supporting programs for the startup community in Vietnam.

\subsection{Managerial implications}

\subsubsection{Implications for potential and existing startups}

This research result is a usable reference for incubators and current e-commerce entrepreneurs for their future success or reduce the potential risk of failure for existing business. Besides, the study provides some inputs for them as followings:

- Vietnam e-commerce market is still huge potentials with a growth rate of 16.5 percent (period of 2017 - 2021), therefore with a right strategic business plan, e-commerce startups get the advantages when penetrating the market.

- To focus on four contributed factors which are Risk-taking propensity, Achievement orientation, Reliability of e-service quality, and E-networking during planning or operating e-commerce business.

\subsubsection{Implications for government}

In addition, the researchers hope to partially contribute to awareness of Vietnam government about e-commerce success in a local context. E-commerce in developing countries like Vietnam is an up-trend, thus it needs to be focused by the government. Vietnam government can take the initiative to improve some areas as below: 
- To develop an information infrastructure which is very basic condition. This will help to ensure the reliability and speed of network, which is essential to ecommerce. Besides that, to establish a common payment method, the national electronic payment system needs to be developed and improved broadly at any e-commerce transaction.

- To improve e-commerce law to boost public confidence in e-commerce business and support e-commerce activities, such as: intellectual property protection, security \& privacy regulation... It will help create a clear procedure for the customer when problem happens during on-line shopping (Pham et al., 2020). On the other hand, it will enhance the trustworthiness of online shopping to the community.

- To encourage e-commerce business, they need to provide the incentive for tax and other fees, as well as administrative procedure such as customs declaration, tax declaration, import and export procedure, business registration process.

- To improve the awareness and understanding of e-commerce to community by providing training, seminars, and related guideline document. Besides that, the government needs to enhance collaboration with regional and international ecommerce. This will help to build a guideline of e-commerce, which aligned with international code.

\section{Conclusion and future research}

In summary, based on literature review, there are nine impact factors on the success of e-commerce startups including: founder related factors, e-commerce service factors, and external factors. Based on this research model, a quantitative research has been conducted in Vietnam. There are 192 validated respondents was collected for statistical analysis using SPSS software. The research model has been tested using multiple regression method. In which, 4/9 hypotheses were supported by the sample data.

Based on the research findings, there are four out of nine factors which significantly contribute to the success of e-commerce startups in Vietnam, including risk-taking propensity, achievement orientation, e-service reliability and founder's e-networking. Among those, risktaking propensity make a large contribution to predict startup's success. From this results, some recommendations have been made for improving the success of e-commerce startups including: 
developing national IT infrastructure, improving e-commerce support regulations, increasing the awareness of society about the important of e-commerce startups...

Some limitations of this research could be summarized as follows: (1) Conceptual framework only focuses on perception of owners'. In other word, these are internal measures which belong to the owners or founders only; (2) Data collection was based on multiple source of e-commerce start-up definitions, led to multiple target respondents. The response from lacking-experience people might provide inaccurate evaluation for e-service quality; (3) Measurement of the dependent variable of e-commerce start-up or entrepreneurial success in this study is only a perception.

Some future research directions could be summarized as follows: (1) The development of measurement scale should cover external factors which belong to the customer point of view about the success of e-commerce entrepreneurs; (2) Future research might need to develop a more accurate measurement of e-commerce start-up success in term of financial statement and employee's growth; (3) A comparative study in other countries within the region is highly recommended to enhance the understanding and increase the applicability of the findings.

\section{Acknowledgments}

I would like to acknowledge gratefully all supports for this research from Ho Chi Minh City University of Technology (Vietnam National University-HCM), MSM-MBA program, and the School of Industrial Management (HCMUT).

\section{References}

Australian Embassy. (2019). Vietnam's Innovation Ecosystem 2019. Retrieved from: http://austrade.gov.au/Vietnam

Blank, S. \& Dorf, B. (2012). The Startup Owner's Manual: The Step-By-Step Guide for Building a Great Company. K \& S Ranch Publisher. ISBN-10: 0984999302.

Bobbitt, L. M., \& Dabholkar, P. A. (2001). Integrating attitudinal theories to understand and predict the use of technology-based self-service: the internet as an illustration. International Journal of Service Industry Management, 12 (5), 423-450. http://dx.doi.org/10.1108/EUM0000000006092

Chakraborty, S. \& Tyagi, P. (2020). E Commerce for Entrepreneurs: Launch your Ecommerce startup with strong technology and digital marketing. BPB Publications. ISBN-10: 9389898404. 
Chen, L., Haney, S., Pandzik, A., Spigarelli, J., \& Jesseman, C. (2003). Small business internet commerce: a case study. Information Resources Management Journal, 16 (3), 17. http://dx.doi.org/10.4018/irmj.2003070102

Choshin, M., \& Ghaffari, A. (2017). An investigation of the impact of effective factors on the success of e-commerce in small- and medium-sized companies. Computers in Human Behavior, 66, 67-74. https://doi.org/10.1016/j.chb.2016.09.026

Dessyana, A. \& Riyanti, P.B.D. (2017). The Influence of Innovation and Entrepreneurial SelfEfficacy to Digital Startup Success. International Research Journal of Business Studies, 10 (1), 57-68. https://doi.org/10.21632/irjbs.10.1.57-68

Jones, S. \& Tynan, M. (2021). 7 Entrepreneurial Leadership Workouts: A Guide to Developing Entrepreneurial Leadership in Teams. Anthem Press. ISBN:9781839981852.

Fisher, R., Maritz, A., \& Lobo, A. (2014). Evaluating entrepreneurs' perception of success: Development of a measurement scale. International Journal of Entrepreneurial Behavior \& Research, 20 (5), 478-492. https://doi.org/10.1108/IJEBR-10-2013-0157

GEM. (2017). Vietnam Startup Index Report. Thanh Nien publisher. Retrieved from: https://www.gemconsortium.org/report/gem-vietnam-20172018-report-executivesummary

GEM. (2020). GEM 2020/2021 Global Report. Global Entrepreneurship Research Association. Retrieved from: https://www.gemconsortium.org/report/gem-20202021global-report

Groenewegen, G. \& De Langen, F. (2012). Critical Success Factors of the Survival of StartUps with a Radical Innovation. Journal of Applied Economics and Business Research JAEBR, 2(3), 155-171. Retrieved from: http://www.aebrjournal.org/uploads/6/6/2/2/6622240/4makalecriticalsuccessfactorsoft hesurvivalofstart.pdf

Hair, J. F., Black, W. C., Babin, B. J., \& Anderson, R. E. (2014). Multivariate data analysis (7. Ed., Pearson new internet. Ed). Harlow: Pearson. ISBN-10: 0138132631.

Kerr, S.B, Kerr, W.R, \& Xu, T. (2017). Personality Traits of Entrepreneurs: A Review of Recent Literature, Working paper of Harvard Business School. Retrieved from: https://www.hbs.edu/ris/Publication\%20Files/18-047_b0074a64-5428-479b-8c8316f2a0e97eb6.pdf

Kuratko, D. F., \& Hodgetts, R. M. (2004). Entrepreneurship: Theory, Process, and Practice. Mason, OH: South-Western Publishers (6th Edition). ISBN-10: 0324258267.

Llewellyn, D. J., \& Wilson, K. M. (2003). The controversial role of personality traits in entrepreneurial psychology. Education+ Training, 45 (6), 341-345. https://doi.org/10.1108/00400910310495996 
Macko, A. \& Tyszka, T. (2009). Entrepreneurship and Risk Taking. Applied Psychology: An International Review, 58 (3), 469-487. https://doi.org/10.1111/j.1464-

0597.2009.00402.x

Nguyen, P. C. (2010). Study international e-commerce models and lesson learnt for Vietnam. Ha Noi: FTU.

Pallant, J. (2005). SPSS survival manual: a step by step guide to data analysis using SPSS for Windows (Version 12). Crows Nest, NSW, Australia: Allen \& Unwin. ISBN-10: 0335223664.

Pham, Q.T. (2017). A Knowledge Management Approach for Ensuring the Success of IT Industries in Vietnam. New York: Nova Science Publishers. ISBN: 9781536128734.

Pham, Q.T., Dang, N.M, \& Nguyen, D. T. (2020). Factors Affecting on the Digital Piracy Behavior: An Empirical Study in Vietnam. Journal of Theoretical and Applied Electronic Commerce Research, 15 (2), 122-135. https://doi.org/10.4067/S071818762020000200108

Pham, Q.T., Tran, X.P., Misra, S., Maskeliūnas, R., \& Damaševičius, R. (2018). Relationship between Convenience, Perceived Value, and Repurchase Intention in Online Shopping in Vietnam. Sustainability, 10, 156, https://doi.org/10.3390/su10010156

Quaddus, M., \& Achjari, D. (2005). A model for electronic commerce success. Telecommunications Policy, 29 (2-3), 127-152. https://doi.org/10.1016/j.telpol.2004.11.009

Reynolds, P. D., Bygrave, W. D., Autio, E., Larry, W. C., \& Hay, M. (2002). Global Entrepreneurship Monitor: 2002 Executive Report. Babson College, Ewing Marion Kauffman Foundation, and London Business School. Retrieved from: http://www.esbri.se/gemglobalreport_2002.pdf

Ries, E. (2011). The Lean Startup: How Today's Entrepreneurs Use Continuous Innovation to Create Radically Successful Businesses. Crown Business. ISBN-10: 9780307887894

Santos, J. (2003). E-service quality: a model of virtual service quality dimensions. Managing Service Quality: An International Journal, 13 (3), 233-246. https://doi.org/10.1108/09604520310476490

Santos, E. A., \& Torkomian, A. L. V. (2021). Characteristics of the digital entrepreneur: a multicase study in startups. International Journal of Innovation - IJI, 9(2), 219-238. https://doi.org/10.5585/iji.v9i2.18562

Sebora, T. C., Lee, S. M., \& Sukasame, N. (2009). Critical success factors for e-commerce entrepreneurship: an empirical study of Thailand. Small Business Economics, 32 (3), 303-316. https://doi.org/10.1007/s11187-007-9091-9

Sung, T. K. (2006). E-commerce critical success factors: East vs. West. Technological Forecasting and Social Change, 73 (9), 1161-1177. https://doi.org/10.1016/j.techfore.2004.09.002 
Tabachnick, B., \& Fidell, L. (2007). Multivariate analysis of variance and covariance. Using Multivariate Statistics, 3, 402-407. ISBN 9780134790541

Thornton, J., \& Marche, S. (2003). Sorting through the dot bomb rubble: how did the highprofile e-tailers fail? International Journal of Information Management, 23 (2), 121138. https://doi.org/10.1016/S0268-4012(02)00104-4

Turban, E., Outland, J., King, D., Lee, J.K., Liang, T.-P., Turban, D.C. (2018). Electronic Commerce: A Managerial and Social Networks Perspective, 9th Edition. Springer. https://doi.org/10.1007/978-3-319-10091-3

Van Riel, A., Semeijn, J., \& Janssen, W. (2003). E-service quality expectations: a case study. Total Quality Management \& Business Excellence, 14 (4), 437-450. https://doi.org/10.1080/1478336032000047255

Zeithaml, V. A. (2002). Service excellence in electronic channels. Managing Service Quality: An International Journal, 12 (3), 135-139. https://doi.org/10.1108/09604520210429187 